Year:3, Volume:3, Number:6 / Yul:3, Cilt:3, Sayı:6/2019

DOI Number: 10.30520/tjsosci.616780

\title{
NOSTALGIC EVOLUTION OF MARKETING: RETRO MARKETING
}

\author{
Esra ÖZKAN PİR ${ }^{1}$
}

\begin{abstract}
Along with the postmodern transition of marketing, new concepts in marketing started to emerge. Retro, one of these concepts, has begun to be used as a marketing variable in order to create demand by revitalization in the products that are forgotten or about to be forgotten. Retro marketing aims to introduce products or services in a nostalgic structure. Retro products give pleasure to consumers because they are products that remind us of a past memory event or an object. Therefore, while creating a brand identity and brand image, companies try to appeal to the past aspirations of consumers by aiming to give more pleasure to the consumer. The main subject of this study is retro marketing which has been gained to marketing literature as a contemporary concept. In this study, the concept of retro marketing is examined from various perspectives. First, detailing the relationship between nostalgia and retro, then the characteristics of retro marketing is explained by the differences between traditional marketing and retro marketing with the retro marketing examples in Turkey and the World.
\end{abstract}

Keywords: Marketing, Nostalgia, Retro, Retro marketing

\section{INTRODUCTION}

Marketing consists of the determination of customer needs and desires, the selection of target markets to be successful and the activities related to the goods and services and programs to be offered to these markets. Marketing activities constitute the group's outward activities. There are many external factors that affect marketing activities and decisions need to be made under uncertainty and risk conditions. Marketing is a bridge between the producer and the consumer and brings the parties together. This bridge also enables communication between businesses and all segments of society.

With the acceleration of globalization, the transformation of the industrial society into an information society has affected every aspect of the economic and social life and led to the development of alternative methods in reaching consumers in the marketing world. As a result of these changes in the world, businesses have moved away from traditional marketing approaches and started to apply many modern marketing methods that are customer and market oriented. Some methods have emerged from various sectoral practices and gained a certain quality and some methods that have entered the marketing literature have been shaped in the light of the opinions and ideas of experts and academicians working in this field. In this context; this section discusses some of the most widely used modern marketing methods in practice.

\footnotetext{
${ }^{1}$ Dr.Öğr.Üyesi, Erzincan Binali Yıldırım Üniversitesi, e-mail: esraozkanpir@ gmail.com
} 
With the emergence of post-modern marketing, new concepts began to take place in marketing literature. One of these concepts is retro marketing. Retro marketing is based on an old historical phenomenon. Retaining a service or product purchased in the past is the basis of retro marketing. These products or services are generally offered for consumption in a nostalgic nature. When retro products are generally obtained, they are products that remind us of a past memory, an event, an individual or family or an object of co-existence. The individual connects with the past while consuming these products and services and removes the longing for the past with this bond.

Today, many manufacturers and service providers use retro marketing techniques. With their nostalgic appearance, the products immediately remind the individual of an experience that took place in the old history and directs the individual to buy the product. Retro product advertisements, which have gained a lot of place in the TV market in recent times, the fact that the advertisements of the products remind a square from the past increases the sympathy for these products.

\section{RETRO MARKETING CONCEPT}

\subsection{Retro and Nostalgia}

Retro is used to convey the services and products used in the past to the present in relation to marketing. Retro marketing; While conveying the longing consumers to the products and places they longed for, it also conveys these feelings to young generations who have not experienced it at the time (Demir, 2008: 32). The use of the word retro to describe cultural products and materials was first used in France in the early 1970s. The recent French avant-gard cinema has begun to use to characterize the growing interest in recent styles and trends in Parisian fashion houses and street markets (Y1lmaz, 2006: 24).

It is necessary to explain the term nostalgia in order to understand the contents of retro brands and to determine the effects of brand management (Brown et al, 2003: 19). The term nostalgia consists of the combination of the words 'nostos' which means to return to the homeland and home and 'algos' which means to suffer in the Greek language.Nostalgia; the things that individuals have in their past, the places they live, the people they are in contact with and the emotional reactions they accumulate.According to another definition nostalgia; over-longing and love for past tense (Phelps, 2004:12).In general, nostalgia refers to the meaning that they place on objects according to the individual's past experiences, pain and other emotions (Boym, 2002: 24). Within this definition, nostalgia is used to express the longing for the past and the desire to return to the past and relive that period (Gülay, 2015: 844)

Nostalgia has increasing importance by attracting attention in business life as it has a high impact area and is a convincing marketing method. Recently, there has been a significant increase in interest in nostalgia and consumption experiences in the literature. Nostalgia has managed to attract the attention of marketers with the effects of music, entertainment and themes that create emotional sensitivity especially with the effect of advertisements on product management.In order to uncover nostalgia, marketers are trying to capture the memories, experiences and fantasies of consumers (Hill, 2007:91).In the concept of nostalgia, the social environment in that period is also important and remembering the products of the past reminds the individual of that environment and the past beautiful days (Stauth and 


Year:3, Volume:3, Number:6/Yul:3, Cilt:3, Sayl:6/2019

Turner, 2000: 845). However, it is not correct to limit nostalgia only to the state of emotion attributed to certain products used in the past. Nostalgia is also considered as longing for the distant past in addition to the recent past (Keskin and Memiş, 2011: 192).

The term nostalgia is expressed in different ways by the authors who work in different fields. However, each researcher is independent of the specific contexts in which the subject is examined (Toledo and Lopes, 2016: 36);

1. Nostalgia is also a mood, emotion and feeling.

2. Nostalgia services, products, places, people, experiences, ideal history, and expresses a sense of melancholy in relation to brands.

For researchers in the field of marketing, this term has been studied since the 1990s and is important for shaping consumer choice methods (Toledo and Lopes, 2016: 35). Considering the positive aspects of generalized nostalgia, it can be thought that consumers will react positively to brand nostalgia. In this context, this is especially the case if minor changes are made to keep the brand up-to-date, especially when customers continue to use the mark regularly (Shields and Johnson, 2016: 714).

Retro products have superior functions and harmonize the present with the past (Brown, 1999: 365).

There has been an increasing interest in nostalgia and consumption experiences in the literature (Kopf and Wolf, 2007: 838). Nostalgia describes the longing for idealized past and experience (Toledo and Lopes, 2016: 35). Research and academics state that nostalgia is a difficult reaction to marketers to predict. The overall effect value of nostalgia, which is a complex combination of negative and positive senses, can be interpreted as plain and unclear (Solomon, 2001: 439).At this point, nostalgia is becoming an issue that marketing experts consider in practice. For example, it is seen that marketing strategies containing items that remind the childhood or holidays of the middle-age population are applied intensively (Tekeoğlu and T1ğl1, 2016: 253).Nostalgic products, when one sees the experience of ancient history, a situation, an event, and encourages the person to buy the product (Yüksel, 2014: 8).

From a marketing perspective, nostalgia can be marketed repeatedly. Social and personal nostalgia is not so intertwined in any field other than marketing. Interest in the term nostalgia is increasing in the field of marketing, especially in relation to the behavior of consumers, along with the attitude, intention to buy, and advertising for a brand (Toledo and Lopes, 2016: 36). Longing for the past (Davis 1979: 23) is embodied in individuals' efforts to revive some traces of the past in their present lives. The trend of nostalgia and postmodernism manifests itself in the field of service and marketing with product development and promotion methods and efforts.

\subsection{Definition and Characteristics of Retro Marketing}

Retro Marketing, which emerged as a brand new marketing term today, was first introduced by Stephen Brown. Brown defined retro marketing as a re-start or revival of products or services from the past (Gallagher, 2004: 163). Marketers use the phenomenon of nostalgia to specifically target postmodern consumers (Odabaş1, 2014: 33).Retro marketing; reuse of an application or icon that reminds us of the past of a brand or product in the past (Tekeoğlu and T1ğl1, 2016: 280).Retro marketing, renewal, reshaping, return, resuscitation is about the rebirth or repetition of old products. Retro brand and product are modern in functionality and usability today, but old in appearance and feel (Ogechukwu, 2014: 3334). 


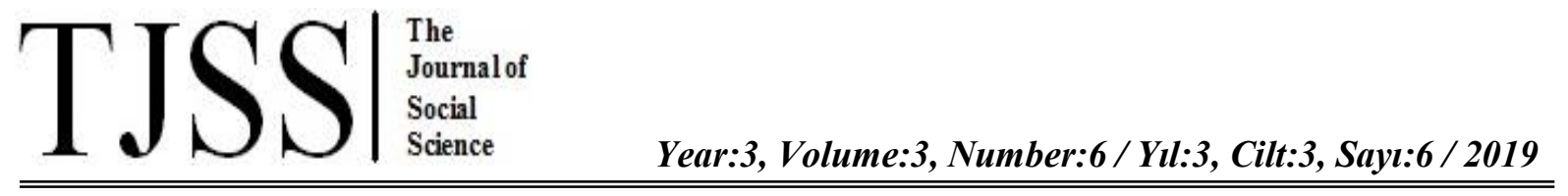

Retro marketing is defined as the past, which has worked or failed in past tenses, which consists of habits or doctrines that we do not do anymore, and which prevents to make a difference. According to another definition, retro marketing is a nostalgia referenced marketing which is formed by the revitalization of past events, brands and fashion (Dağdaş, 2013:12). When defining the concept of retro marketing, it is stated that the product or service which is used in the recent past and is located in the market is taken into consideration again and marketed with new and past marketing strategies (Demir, 2008: 32).

The idea behind retro marketing is that a film that is being watched and influenced, traces of something from the life of the individual or family when individuals make decisions about the product during the purchasing phase. That is to say, due to the fact that the recent retro term is largely reconciled with the longing for the past, customers have also demanded the social conditions, way of living and other characteristics of that period. For this reason, it can be said that retro marketing is the most cost-effective method to use individuals' loyalty to the past due to the developments (Korkmaz et al., 2009:87).

Retro marketing, which can be expressed as re-use of an existing product, brand or an application or figure reminiscent of the past in today's conditions, meets the customers in different forms (Tümbek-Tekeoğlu and T1ğl1, 2016: 280).

Retro marketing is generally seen in three groups.

Repro is to reproduce objects that were beautiful in the past.

Retro combines the old with the new in a different way from repro.

Repro-Retro; refers to improved products starting from nostalgia. Repro-retro is also called Neo-nostalgia.(Levinson, 2008: 22).

\section{RETRO APPROACHES USED IN MARKETING}

Persons interested in history know that too many things that are supposed to be new are not actually new, but that they are revised in a different way, technique or packaging. It is also possible from time to time to present new ideas with the old packaging. Therefore, it is possible to produce a variety of differences between the old and the new. Marketing reinforces innovation through the retro term (Brown, 2001b: 3-4).

Big and well-established brands are turning to retro product studies especially on their anniversary.The nostalgic appeal is also evaluated in brand message strategies to differentiate or achieve a successful position. Nostalgic production and message strategy aim to awaken the desire to lead to the past.The past tense perceived as superior to the present time is embodied in the memories based on the predicted items that consumers have missed in the past, or on historical elements where they have no chance of reuse.The main objective of nostalgic production and message strategy is post-modern individual.The post-modern person is happy to establish a relationship with the past and to carry this relationship to the day it is lived.Post-modern consumers will want to evaluate consumption experiences in search of sensuality passion and social bond (Shindler and Holbrook, 2003:275).

Brands are increasingly using the concept of retro to reach consumers. However, the idea of using the past is not a new trend (Clemente-Ricolfe and Enguer-Goslbez, 2018: 380). There are important similarities between nostalgia, brand heritage and brand revival. Revived products or retro products take advantage of consumers' nostalgic tendencies.For example, familiar slogans and packages remind of brand heritage and evoke the better days of consumers in both personal and social terms (Brown et al., 2003b: 20).

The styles of retro brands should be combined with the latest technology to provide a competitive advantage. Accordingly, retro brands should be in the sense of "old fashioned, 
new presentation" that the good old days should be harmonized with contemporary times (Merlo and Perugini, 2015: 95).

Today, too many companies in the consumer goods market rely on nostalgia to increase product sales, and an increase in the re-launch of nostalgic products is observed in the market.An example of this is the reissue of the Volkswagen Beetle, or the reunion of classic films, old theaters with the audience. Market review data show that such initiatives some products to market with nostalgic segment are likely to be successful (Shields and Johnson, 2016: 359).

In promotion activities, where nostalgia is actively involved, brand name, brand writing, logo, advertisement, reinforcement with mythical events or products in advertisements, yet unforgettable images in the past, music or bottling, packaging with traces of the past, leaving the impression of rootiness. traditions, beliefs, myths or fame that reflects the culture of the past and the development of this radicalism and the difficult path revealed by this product is processed in a way to engrave the minds of customers in the advertising of the product (Eser, 2007: 126).

In the case of historical nostalgia, the details necessary for the imagination to reflect and resemble the truth will be provided by description. In this context, the details (interior decor, costume, architecture, etc.) chosen according to the place, character, culture and time are used.Advertisements that make use of historical nostalgia tell stories about brands, consumer goods and product styles that aim to empathize people with the past. If representative participation can be triggered in a historical period, its creative features can generate positive beliefs about the personal relevance of the product (Demir, 2008: 37).

\section{REASONS WHY BUSINESSES PREFER RETRO MARKETING}

Given the perceived need for individuals to maintain their personality in historical transition periods, retro marketing is the commercial answer to this need, as it focuses on customer nostalgia and the emotional ties that customers establish over time with classic products and brands (Brown, 2013: 522). Today, consumers demand applications and products that stimulate past habits synthesized by technology and scientific developments. Retro marketing aims to revive the forgotten or almost forgotten products and to create a demand for these products (Şahin, 2013: 93).

Businesses use the retro style in the field of marketing communication both locally and globally. Referencing history when it comes to local marketing campaigns; it underlines local authenticity, history and tradition. In the case of global brands, retro marketing is particularly used to emphasize exclusive brand traits, history and eternal values. The objectives of these retro marketing are to focus on improving brand value and strengthening brand image (Grebosz and Pointed, 2015: 121-122).

From the company's point of view, there are four main motivations in implementing the retro-marketing method (Brown, 1999: 365; Brown et al., 2003: 20).

Retro Marketing,

1. Retro marketing, a brand management approach, can be considered as an alternative to sustaining brand heritage.

2. Since the original version of the existing product proves itself against consumers, it is the way to minimize risks in order to be successful during the launch of a new product.

3. There may be a way to benefit from existing experiences and resources.

4. A retro product can be produced in response to similar attacks from competitors. 


Year:3, Volume:3, Number:6/Yul:3, Cilt:3, Sayl:6/2019

Businesses need quick solutions from time to time. Reasons for using past tenses in brand communication methods, although existing nostalgic memories are not the same as one by one, nostalgic memories eliminate negative situations, change semantic content and give information about the past with nostalgic interpretations (Kessous, 2014: 50).

It is obvious that well-established companies that carry out retro marketing activities are fed from their own past in this context.Businesses will achieve their goals with Retro marketing activities if they combine the new and the old tremendously and accurately promote it to the target audience, especially to the audience who already knew that product from the past. Although retro marketing is a relatively simple process, it can be challenging for businesses if it is not executed with the right strategy (Şahin and Kaya, 2019: 244).

Revitalizing an old brand means a lower cost than creating a new brand. Moreover, every new brand is like a journey with no end. There is always the possibility of success or note (K1ziltan, 2015). According to the results of the US-based research firm AcuPoll; After a long investment in new product development, 95 percent of the new brands introduced to the market every year fail or fail to make an impact.For this reason, many companies prefer to revive an old brand instead of creating a new brand while developing a new product (http://thebrandage.com/olu-markalara-hayat-opucugu/).

Retro marketing has been an important strategy element on behalf of marketing practitioners in order to awaken sleeper brands and to emphasize the long-standing history of the brands that still survive. In particular, marketing practitioners eliminate the risks that they will face with a new brand by building on their existing strategies and taking advantage of the past experiences of brands (Keskin and Memiş, 2011: 200).

Businesses should remind the consumer the right product in the right way. It should be clearly stated that a brand new product in the taste of nostalgia is presented to the target audience and the product should be promoted as required.Retro marketing; mind, nostalgia, commitment sensuality, innovation concepts, and these concepts nurture the sense of awareness and trust.Therefore, retro brand trends affect the awareness and trust of the brand. Rooted brands that apply to retro marketing in their marketing activities should first stimulate consumers' awareness and trust and choose the right strategies to revive the brand already in mind.If they act like this, advantages such as gaining sympathy, preference, loyalty will come along with cost (Şahin and Kaya, 2019: 244).

\section{COMPARISON OF RETRO MARKETING WITH MODERN AND POST- MODERN MARKETING}

As a result of modern marketing approach, marketers focus on customers and constantly follow the needs of customers, develop new products and strive to provide customer satisfaction (Brown, 2001a: 83). Retro marketing offers a different marketing approach with its past connotations contrary to the modern marketing concept. Past references refer not to the exhaustion of innovations but to the dynamism of reverse marketing (http://pazarlamabitanedir.blogspot.com, 2010).

The changes and developments experienced with the arrival of the post-modern era have integrated itself into art, architecture, artist and every stratum of society and have shown its effect and change everywhere. With the change of environment, television programs and series have changed and the type of music that the people listen to has become one of the differentiating processes. One of the greatest benefits of post-modernity is that the longing for nostalgia increases and progresses in line with supply and demand, and it is important in 


Year:3, Volume:3, Number:6/Yul:3, Cilt:3, Sayt:6 / 2019

every platform. The retro effect is seen from fashion, architecture, art, music to the nostalgia (Gülay, 2015: 700).

Postmodernism; sociology, psychology, economics, etc. has led to a number of changes in marketing as well as in other areas. Postmodern culture has caused new changes starting from the external environment embracing marketing to the concept of one-to-one marketing.The postmodern perspective aims to ensure that ties with the present and the past are not severed, rather than the present. In this respect, postmodern marketing coincides with retro marketing. The desire to add the past and the future to experience together leads to the rediscovery of the traditional and the sacred, the attainment and the use of it. The tendency of the postmodern individual to try many things together at the same time perhaps created the perception that the past and the future can be tried together (Yeygel, 2006:207).

In today's fast-paced social and technological changes, consumers are looking for and familiar with what they are familiar with in the past. Many marketing executives, especially those facing high media costs and the risk of creating new brands, benefit from past brands and products by redesigning or repackaging them. The benefits of reusing old and non-existent brands and products in the past show that old is fashionable again and that innovation doesn't always mean something new (Korkmaz et al., 2009: 86).

In contrast to modern marketing, retro marketing has brought a different dimension to marketing literature as it has an effect that prolongs product life periods or starts these periods again. Despite some criticisms, retro products make an important contribution to the product's retention by reflecting the irresistible effect of nostalgia on consumers (Keskin and Memiş,2011:200).

\section{EXAMPLES OF THE RETRO MARKETING IN TURKEY AND THE WORLD}

There are various examples of the use of retro in marketing. Retro marketing in the world as an example, the Volkswagen New Beetle model built on the brand legacy of the modern brand. The New Beetle was designed by automotive designer Ferdinard. The vehicle has increased its popularity after World War II throughout Europe and North America. Volkswagen Beetle is globalized with its strength, economy, user-friendliness and unique design.Hippies, middle-class couples, even the children of multi-millionaires used Beetle. In addition, Beetle is presented as a smart, golden-hearted vehicle in the Disney movie "Love Bug" (Keskin and Memiş, 2011:192).

As a retro brand, Phantom Menace's contemporary actors have created a brand based on a new film using technology and special effects. As with the New Beetle, a product related to creativity is created with the current product(Brown vd., 2003:148).

Republishing an old black-and-white ad is costly for the business.Older ads are fun, especially after the latest technology has been reformatted. However, in repro catching nostalgia is simpler.The Historic Collections Group, founded in 1986, can be given as an example. This group established a chain of retro souvenir stores of the past. In seventy retail outlets, historic decorative home furniture and figurines are sold. As a rule:tores belonging to this group should be established in prestigious locations (Regent Street, Trafford Park, etc.) (Brown, 2001b: 6).

Another example of retro marketing in the world is Star Wars: I-Phantom Menace. Star Wars: I-Phantom Menace is a long-awaited brand revival from the famous trilogy of George Lucas in the 1970s and 1980s (Star Wars 3rd film I-Phantom Menace shot in 1998). In 1977, the first Star Wars movie space vehicles:mart robots and fairy tale somewhere away 


Year:3, Volume:3, Number:6/Yul:3, Cilt:3, Sayt:6 / 2019

from the world was created to amaze consumers.Star Wars: I-Phantom is branded for retroconnected products and services for today's fun economy (Wolf, 1999: 23).

In 2000, Nokia sold 126 million of its 3310 models, making it a well-known phone brand. The new generation Nokia 3310 was introduced at the 2017 mobile world congress in Barcelona. (http://www.serhatdalgalidere.com). The "father watch" model of the Casio brand is re-launched (https://www.marketingturkiye.com.tr). Again, the Chrysler PT Cruiser combines the latest automotive technology with the 1940s sedan form to produce a car of the past with the design of history, and the Nike, which was the symbol of the dreams of the pots of the 1950s, but with comfortable underbeds, ventilated top and recommended retail prices. Michael Jordan I Retro Sneakers is one of the prestigious restaurants of the 1950s, today Denny's retro restaurant with computer-powered safe records, a well-equipped kitchen and a non-smoking vegetarian dining area can be given in the sense of good examples (Brown, 2003b: 20).

Fruko soda in Turkey, Vita, Tipitip, Rebul cologne, Sarelle, Tadelle and many more brands on the market have increased by renewing themselves. Many brands, such as Coca Cola, which have existed for years, have redesigned their old bottles and released them to the market and reminded the past. Turkey's Isbank published since 2013, and the bank yesterday and today retro advertising refers to ads that are examples (http://www.pazarlamasyon.com). Zeki Müren's first "I call you ALO" song campaign was re-used with the current version. ALO 7 to 70 everyone is very much loved and respected sound artist Zeki Müren in the same advertising film brought back to the consumer (http://www.thebrandage.com).

Finally, as examples of retro products in Turkey, Migros October 2011 between the organizations in Turkey 57th anniversary of the country's many brands has also introduced 50 years ago with the re-design and consumer prices. In this context, Coco-Cola's nostalgic bottle designed years ago, Ülker's canister biscuit, carton packaging of palate chocolate, classic hat figure with a cute hat, Noah's Ankara Pasta, Koska Halva, Sana oil, Komili oil, Arko products are aimed to experience nostalgia. In addition, the company introduced the Migros sales trucks, which have become a symbol in the past, to the customer with a new concept. (www.sabah.com.tr, 2011).

\section{RESULT}

Nostalgia, which touches emotions stimulates them and creates moments of happiness, has become important in the world of both consumers and marketers. In this process, a wide variety of cases had an accelerating effect. The most important effect was the loss of values that make sense of personal lives. This sense of loss and the unknowns created by the future; It has led people to embrace the nostalgia that will lead them to the memories of the past and transfer those memories to the present. Emotions triggered by nostalgia have been in the field of marketing with its economic value as well as the spiritual satisfaction it provides to the consumer. This development was influenced by retro marketing practices, which focused on the consumer's interest in the past and removed from marketing-oriented sales. Retro marketing, based on values, participation and collaboration with consumers, retro marketing based on time-based and spatial visualizations, experiential marketing aimed at five senses, is trying to gain consumers' trust while creating new consumer objects with various methods such as scent-based marketing approaches and long tail model provided by digitalization. In this context, nostalgia acts as a bridge in the world of consumption that connects them to each other by creating a common line of value that brings both the consumer and the marketer and replaces the lost. The continuous functioning and gaining meaning of this process will 


Year:3, Volume:3, Number:6/Yul:3, Cilt:3, Sayt:6 / 2019

depend on the awareness of consumers and the internalization of the ethical values of businesses.

Retro marketing has become one of today's popular trends. A significant number of manufacturers have followed this trend and offered products to consumers in this direction. Retro marketing, which puts forward its marketing strategy by using the products and brands of the past period, provides the brand image to the consumer by using the brand heritage with the products and brands that the company offers to the consumers in the past. However, brands' past experiences or practices based on nostalgia support this effort. Therefore, it can be stated that the concepts of nostalgia and revitalization of brands generally overlap with each other. While trying to awaken the emotions of the customers with nostalgia, descriptive brand identity elements such as brand symbols, colors and characters are used in marketing activities in the usual style. Retro marketing has been an important strategic element in order to awaken sleeper brands and to emphasize the long-standing history of the brands that are still alive. In particular, marketing practitioners take advantage of the brand's past experience, in other words, to eliminate the risks that they will enter with a new brand by building their strategies on the existing attitudes of consumers.

The fact that societies are consuming more rapidly has strengthened the hand of sellers and increased the options offered to consumers. With the advances in technology, the masses, who always want better and more new, have led manufacturers to tend in this direction and develop products or services in this direction. The products that reflect the positive benefits brought by technology make the lives of consumers easier and add innovation either visually or as a service. This demand of the consumer has led to high competition among the producers and a struggle to offer the better to the consumer. On the other hand, the differences between the products and services offered are low due to the continuity of technological developments, observable consumer reactions and the fact that innovations can be imitated by others. This makes it very difficult for sellers who promise to offer the "newest" to consumers.

Retro marketing reaches the consumer in a way that stimulates the emotions he/she has experienced in the past and the product it is connected to in the past which is presented to the consumer in accordance with today's conditions. The basic strategy is to revive past emotions and reflect the consumer's bond from the past to the present. Today the number of retro spaces and products is increasing rapidly. This enables the development of retro marketing. In addition to consumers longing for the past, the new masses that enjoy the texture of the past are also included in the target audience of retro marketing.

In today's market conditions where competition is very high, there is a strong possibility that enterprises will increase their interest in retro marketing. Along with increasing technology, changing lifestyles and changes brought by modernity lead to an increase in people's longings for the past. For this reason, retro marketing is not a periodic development but continuous development. The fact that technology is effective in every area of life increases the longing for the simplicity and serenity of the past. Therefore, it is possible to accept retro marketing for all sectors instead of classifying them as sectoral. Retro marketing is a process that is easy to develop and marketable as it is possible to directly address the consumer's connection with the past by using features such as logos, music, labels or packaging. 


TJSS|

\section{REFERENCES}

Brown, S. (1999). Retro-marketing: Yesterday's tomorrows, today!.Marketing Intelligence \& Planning, 17(7), 363-376.

Brown, S. (2013). Retro from the get-go: reactionary reflections on marketing's yestermania. Journal of Historical Research in Marketing, 5(4), 521-536.

Brown, S. Kozinets, R.V. Ve Sherry J.F. (2003a). "Sell Me the Old, Old Story: Retro marketing Management and the Art of Brand Revival", Journal of Customer Behaviors, 2(2):s. 133-147.

Brown, S., Kozinets, R.V. and Sherry, J.F. (2003b). Teaching old brands new tricks: retrobranding and the revival of brand meaning, Journal of Marketing, 67(3), 19-33.

Brown, S. (2001a), “Torment Your Customers (They'll Love It)”, Harvard Business Review, Volume 79/9, p.82-88.

Brown, S. (2001b), "Marketing: The Retro Revolution", Sage Publication.

Clemente-Ricolfe, J. ve Enguer-Goslbez, P. (2018). "Exploring the Potential Market for Retro Products: An Empirical Analysis”, Italian Sociological Review, 8 (3): 379-396.

Dağdaş, G.,(2013). İşletmelerde Retro Pazarlama Uygulamalarının Müşteri Bağlılı̆̆ına Etkileri Üzerine Bir Araştırma. Yüksek Lisans Tezi.Selçuk Üniversitesi: Konya.

Davis, Fred (1979), "Yearning for Yesterday: A Sociology of Nostalgia", Free Press, New York.

Demir, F. O., (2008), "Pazarlamanın Nostaljik Oyunu: Retro Markalama", İstanbul Üniversitesi İletişim Fakültesi Dergisi. 33(1):s. 29-41.

Eser, Z. 2007. "Nostaljinin Pazar Bölümleme Değişkeni Olarak Kullanılması Üzerine Kavramsal Bir Çalışma”. Ticaret ve Turizm Eğitim Fakültesi Dergisi, 1(1):s. 115-130.

Gallagher, B. (2004), Gerilla Pazarlama ve Markalasma, http://www.marketingturkiye.com/yeni/Soylesiler, Erişim T: 20.03.2009.

Grbosz, M. ve Pointet, J., M. (2015). "The "Retro" Trend in Marketing Communication Strategy of Global Brands", Journal of Intercultural Management, 7 (3): 119132.

Gülay, B. (2015). Nostalji markalaşmasında post-modern pazarlama örneği: Retro müzik. International Journal of Social Sciences and Education Research, 1 (3), 699-707.

http://pazarlamabitanedir.blogspot.com, 12.03.20109.

http://thebrandage.com/olu-markalara-hayat-opucugu/

http://www.pazarlamasyon.com/reklam/15456/, Erişim Tarihi: 22.04.2019. 


Year:3, Volume:3, Number:6 / Yul:3, Cilt:3, Sayt:6 / 2019
$\begin{aligned} & \text { The } \\ & \text { Social } \\ & \text { Science }\end{aligned}$

http://www.sabah.com.tr/Ekonomi/2011/09/29/migros-fiyatlari-50-yil-oncesinecekti, 23.11.2018.

http://www.serhatdalgalidere.com/yeni-nokia-3310-efsane-mi-pazarlama-stratejisi-mi/, Erişim Tarihi: 22.04.2019.

http://www.thebrandage.com/dosya-konusu-son-doenemin-modasi-retro-pazarlama, Erişim Tarihi: 22.04.2019.

https://www.marketingturkiye.com.tr/haberler/son-zamanlarin-gozde-furyasi-retropazarlama/, Erişim Tarihi: 22.04.2019.

Keskin, H. D. Ve Memiș: (2011). "Retro Pazarlama Ve Pazarlamada Uygulanmasına Yönelik Bazı Örnekler":üleyman Demirel Üniversitesi İktisadi Ve İdari Bilimler Fakültesi Dergisi, 16 (3):s. 191-202.

Kessous, A. (2014). "Nostalgia, autobiographical memories and brand strategy: Marketing to the Post World War Generation", Journal of Brand Strategy, 148-164.

Kiziltan, $\quad$ E.(2015).http://www.turkishtimedergi.com/pazarlama/tavan-arasi-markalarkiymetebindi.

Kopf, D., \& Wolf, M. (2007). Nostalgia and the need for social connectedness: Implications for marketing management. Southwest Decision Sciences Institute, 837-846.

Korkmaz, S., Zeliha Eser: Ayşe Öztürk ve F. Bahar Işın (2009), “Pazarlama: Kavramlar- Ilkeler-Kararlar”:iyasal Kitabevi, Ankara.

Levinson, J. C., (2008), "Guerilla Insights", www.gmarketing.com/tactics/weekly167.html, Erişim Tarihi: 18.07.2018.

Merlo, E. ve Perugini M. (2015), "The Revival of Fashion Brands Between Marketing and History", Journal of Historical Research in Marketing, 7 (1): 91-112.

Odabaşı, Y. (2014). Postmodern Pazarlama: Tüketim ve Tüketici, K. Demirgil (Ed.). İstanbul: MediCat Yayınları.

Ogechukwu, D., A. (2014). "As It Was in the Beginning:o Shall It Be, World Without End Retro-Marketing: the Art of Bringing Back to Life/Revitalizing an Old Brand (Product) - The Nigerian Experience", British Journal of Marketing Studies, 2 (1): 3258 .

Phelps, J.E. (2004). Viral Marketing or Electronic Word-of-Mouth Advertising: Examining Consumer Responses and Motivations to Pass Along Email. Journal of Advertising Research 44 (4).

Schindler, R. M., \& Holbrook, M. B. (2003).Nostalgia for early experience as a determinant of consumer preferences. Psychology \& Marketing, 20(4), 275-302.

Shields, A. B., and Johnson, J. W. (2016). Childhood brand nostalgia: A new conceptualization and scale development,Journal of Consumer Behaviour, 15, 359369.

Stauth, G., \& Turner, B. S. (2000).Nostalji, Postmodernizm ve Kitle Kültürü Eleştirisi. Modernite versus Postmodernite, 405-424. 
Şahin, E. (2013). "İlişkisel Pazarlamanın İşletme Performansı Üzerine Etkileri: Yetkili Otomotiv Acenteleri Üzerine Bir Araştırma". Doktora Tezi:elçuk Üniversitesi Sosyal Bilimler Enstitüsü İşletme Ana Bilim Dalı.

Şahin, E., \& Fatma, K.(2019). Retro Pazarlama Kapsamında Tüketicilerin Retro Marka Eğilimlerinin Retro Marka Farkındalığına Ve Retro Marka Güvenine Etkisi: Konya İlinde Bir Araştırma. Fırat Üniversitesi Sosyal Bilimler Dergisi, 29(1), 227-248.

Tekeoğlu T., N. ve Tığlı, M. (2016). "Retro Pazarlama Açısından Halen Varolmayan Eski Markaların Tüketiciler Tarafından Anımsanması ve Tanınması Üzerine Bir Pilot Çalışma”, Kastamonu Üniversitesi İktisadi ve İdari Bilimler Fakültesi Dergisi:ayı: 12: 278-290.

Toledo, A. C., \& Lopes, E. L. (2016).Effect of nostalgia on customer loyalty to brand postmerger/acquisition.Brazilian Administration Review, 13(1), 33-101.

Tümbek Tekeoğlu, N., \& Tiğlı, M. (2016).Retro Pazarlama Açısından Halen Varolmayan Eski Markaların Tüketiciler Tarafından Anımsanması Ve Tanınması Üzerine Bir Pilot Çalışma. Kastamonu University Journal of Economics \& Administrative Sciences Faculty, 12.

Wolf, M. J. (1999), "The Entertainment Economy: The Mega-Media Forces That are Re-shaping Our Lives", Penguin Putnam, New York.

Yeygel, S. (2006), "Postmodern Toplumsal Yapinın Pazarlamaya Getirdiği Yeni Boyut: Topluluk Pazarlaması (Tribal Marketing)", Bilig:ay1 38:197-228.

Y1lmaz, M. (2006).Modernizmden Postmodernizme Sanat. Ankara: Ütopya.

Yüksel, M. S. (2014). Modern Pazarlamada Yeni Bir Yaklaşım: Retro Pazarlamanın Tüketici Algısına Etkisi.Kahramanmaraş Sütçü İmam Üniversitesi Sosyal Bilimler Enstitüsü İşletme Anabilim Dalı, Yüksek Lisans Tezi, Kahramanmaraş. 